Alicja ŁaWIAK

Uniwersytet im. Adama Mickiewicza

w Poznaniu

\title{
THE IMAGE OF FEMININITYAND MASCULINITY AS A RESULT OF THE SOCIALIZATION PROCESS IN CONTEMPORARY WORLD
}

\begin{abstract}
AвSTRACT. Ławiak Alicja, The Image of Femininity and Masculinity as a Result of the Socialization Process in Contemporary World [Obraz kobiecości i męskości jako rezultat procesów socjalizacji we współczesnym świecie]. Studia Edukacyjne nr 50, 2018, Poznań 2018, pp. 425-440. Adam Mickiewicz University Press. ISSN 1233-6688. DOI: $10.14746 /$ se.2018.50.28
\end{abstract}

The main purpose of this paper are gender stereotypes, which determine an image of femininity and masculinity in contemporary culture. The paper considers the consequences of compartmentalization. The author presents her own research about the stereotypes which create an image of femininity and masculinity in contemporary culture. The text concerns the problem of specific developmental limitations, which are hidden behind the aforementioned compartmentalization. The author based her research and theoretical inspiration on social psychology and social pedagogy (interconnected via socialization).

Key words: femininity, masculinity gender stereotypes, development, contemporary culture

This article shall be started by the reference to some crucial notions connected to the subject of this discourse. First, let me introduce the title feminity and masculity. There is no doubt that both these terms are connected somehow with the gender differences. Basing on these differences, the classification into the men's and women's world was made already by primitive peoples. The women's world was associated with fertility, ground, water and children, while the men's world was associated with sky, war and rain. A peculiar dichotomy was also seen in the mythology: masculity - feminity. Finally, the most pioneering and the most popular concept characterising this contrast develops, namely a biblical delineation of man and woman. ${ }^{1}$

${ }^{1}$ E. Mandal, Kobiecość i męskość. Popularne opinie a badania naukowe, Warszawa 2003. 
Feminity and masculity seem to be generated by ostensible stereotypes. According to Chlewiński ${ }^{2}$ the stereotype is some formulaic pattern, the impression which cannot be surmount. Stereos in Greek means "tough" and typos is the mentioned above "pattern, impression". Stereotypes create some images in our heads, they are the result of a social message, they constitute the simplified image of reality, which is resistant to any changes. ${ }^{3}$ They always concern a particular group of people, isolated based on its representative features, such as: gender, nationality, race, profession or social background. ${ }^{4}$ Moreover, stereotypes are marked by laxity, as they consist of only selected information connected to a particular subject, generalising about the knowledge of the individual based on fragmentary albeit specific experiences. ${ }^{5}$

Stereotypes which concern gender are called gender stereotypes - "constellations of mental and behavioural features which are in the particular culture more commonly assign as characteristic to one gender than to the other" ${ }^{6}$ The generalisations presented above consist of some syndromes, behaviours and principles which are used in the course of every social interaction, further, over making expectations towards ourselves and other members of the society. ${ }^{7}$ Gender stereotypes pertain to many categories. One of them is gender roles, which, according to $\mathrm{Mandal}^{8}$ are the set of opinions and beliefs about both activities performed by men and women and which of them are appropriate for each gender. These activities concern mainly professional duties.

Perspective prejudices are formed by the socialisation. Wincenty Okon defines the term of the socialisation as the set of changes which are made in a person by social influence which creates the individual into a legitimate, sterling member of the particular society. ${ }^{9}$ Buczkowski ${ }^{10}$ states that the socialisation has impact on the person's personality. The personality consists of the character and the temper that is what we inherit, what we are born with and what we acquire from the social environment. ${ }^{11}$

The personality seems to be some category of gender stereotypes collaterally to social roles. Another set of features are: realm of appearance, pro-

2 Z. Chlewiński, Stereotypy: struktura, funkcje, geneza. Analiza interdyscyplinarna, [w:] Stereotypy i uprzedzenia, Eds. Z. Chlewiński, I. Kurcz, Warszawa 1992.

3 E. Mandal, Podmiotowe i interpersonalne konsekwencje stereotypów związanych z płcia, Katowice 2004.

4 B. Wojciszke, Człowiek wśród ludzi. Zarys psychologii społecznej, Warszawa 2003.

${ }_{5}$ M. Grabowska, Stereotypy ptci we wczesnej dorosłości, Bydgoszcz 2007.

${ }^{6}$ E. Mandal, Podmiotowe i interpersonalne konsekwencje, p. 15.

7 L. Brannon, Psychologia rodzaju. Kobiety i mężczyźni: podobni czy różni, Gdańsk 2002.

8 E. Mandal, Podmiotowe i interpersonalne konsekwencje.

9 W. Okoń, Nowy stownik pedagogiczny, Warszawa 2001.

10 A. Buczkowski, Dwa różne światy, czyli jak socjalizuje się dziewczynkę i chłopca, [w]: BrachCzaina, Od kobiety do mężczyzny i z powrotem. Rozważania o ptci w kulturze, Białystok 1997.

11 G. Allport, Personality: A psychological interpretation, New York 1937. 
fession $^{12}$, and according to Długołęcka ${ }^{13}$ even sexual life. Moreover, the behaviour components may be distinguished in here. Grabowska ${ }^{14}$ differentiates attributes describing man and woman. In compliance with gender stereotypes, women are seen as: sensitive, delicate, flirtatious, intuitive, careful, romantic, profligate, curious, emotional, talkative. Moreover, they are characterized by changing moods, love to children, gossiping, taking care of home and as unskilful drivers. Whereas men are proud, bold, however; selfish, love sport and alcohol, are full of self-confidence, physical and mental strength, abilities connected with decision making and can drive a car. Masculity is connoted with mess, not showing emotions, thralling, work activity and jealousy. As mentioned above, there may be distinguished six components of gender stereotypes (see Table 1). The realm of appearance consists of four attributes of both men and women. Charm, cleanliness, subtle voice and soft moves are certainly connected with woman. However, strength, robustness, tallness and broad-shouldered figure are connected with man. The female personality consists of: curiosity, warm in social relations, commitment, care of other's feelings, fondness, sensitivity, understanding, helping and emotionality. Typical male features connected with personality are: ease in decision-making, sense of leadership, activity, self-belief, independence, not undergoing the pressure, proficiency, jealousy and reliability. Women are usually connoted with professions as: telephonist, nurse, therapist, speech therapist or primary school teacher. Men are associated with lorry drivers, insurance agents, chemists, telephones fitters and mayors. The components of social roles performed by women are activities such as: house management, being an emotional support to others, taking care of children or decorating the house. According to stereotypes, men should financially support the family, repair the house, spearhead and be the head of the household. Concerning a behaviour, we believe that women gossip, have changing moods and tease, while men do not cry, do not show emotions and are messy. ${ }^{15}$ Długołęcka ${ }^{16}$ additionally states that there is a set of stereotypes relevant to sexual life, related to men and women. It is commonly assumed that women cannot get pleasure out of sex without sense of emotional connection. Moreover, they have greater control on their sexual needs. Concerning men, situation in on the contrary, as they can get pleasure out of sex even without emotional connection and they have fewer control on their sexual needs.

As can be noticed, both male and female gender have peculiar set of features, roles, behaviours and activities which are assigned to them by society.

\footnotetext{
12 E. Mandal, Podmiotowe i interpersonalne konsekwencje.

13 M. Długołęcka, Raport o seksualności Polaków - Pfizer, Warszawa 2002.

14 M. Grabowska, Stereotypy ptci.

15 E. Mandal, Podmiotowe i interpersonalne konsekwencje; M. Grabowska, Stereotypy ptci.

16 M. Długołęcka, Raport.
} 
All of the mentioned above epithets seem to create stereotype ergo some image of man and woman insisted in our minds. Originally there were distinguished only few features characterising both genders. Concerning men, they were: leadership, agency and aggressiveness. Concerning women, they were: dependency, emotionality and passivity. ${ }^{17}$ Nowadays, as presented above, we have more than fifty features.

There is no doubt that stereotypes skew our image of reality, tend to undue generalisations, generalise some social groups and they often prevaricate. The power of gender stereotypes is illustrated by the riddle, cited by Eugenia Mandal. ${ }^{18}$

A boy and his father were victims of a car accident. The father died outright, the son had serious injuries. The ambulance took him to the nearest hospital. The remarkable surgeon was called to conduct an immediately operation to save the boy's life. However, the surgeon entering the operating theatre said: 'I can't operate this boy. It's my son'. The question is: how is it possible? ${ }^{19}$

The most common answers to this question consider that the father was the surgeon somehow and there was some mistake or the kid was adopted. However, none of these answers is correct. The explanation is simpler - the surgeon was the mother of the kid. Why people do not acknowledge that it was simply a mother? We subconsciously think that woman is not suitable to the profession of surgeon. Woman is not strong mentally and does not have others, essential to this job, abilities. Besides, surgeons are always men! - This is what our brain orders us to think. Maybe there is worth to fight with these thoughts? ${ }^{20}$

Table 1

Components of gender stereotypes

\begin{tabular}{|c|}
\hline 1. Appearance \\
\hline$\quad$ Stereotypes related to women: charm, subtle voice, soft moves, cleanliness \\
- \\
2. Personality \\
\hline $\begin{array}{l}\text { Stereotypes related to women: commitment, sensitivity, care of others' } \\
\text { feelings, fondness, warm in social relations, emotionality, helping, under- } \\
\text { standing, curiosity } \\
\text { Stereotypes related to men: self-belief, activity, sense of leadership, ease in } \\
\text { decision-making, independence, not undergoing the pressure, reliability, } \\
\text { proficiency and jealousy }\end{array}$ \\
\hline
\end{tabular}

${ }^{17}$ S. Cross, H. Markus, in: B. Wojciszke, Człowiek wśród ludzi. Zarys psychologii społecznej, Warszawa 2003.

${ }^{18}$ E. Mandal, Kobiecość i męskość.

${ }^{19}$ Ibidem, p. 11.

${ }^{20}$ Ibidem. 
3. Profession

- Stereotypes related to women: primary school teacher, nurse, speech therapist, telephonist, therapeutist

- Stereotypes related to men: chemist, lorry driver, insurance agent, telephones fitter, mayor

4. Social roles

- Stereotypes related to women: decorating the house, being an emotional support to others, house management, taking care of children

- Stereotypes related to men: repairing the house, financial support of the family, being a spearhead, being the head of the household

5. Sexual life

- Stereotypes related to women: have greater control on their sexual needs, get pleasure out of sex only with sense of emotional connection

- Stereotypes related to men: have fewer control on their sexual needs, get pleasure out of sex without sense of emotional connection, even with strangers

6. Behaviour

- Stereotypes related to women: gossiping, flirtatious, have changing moods

- Stereotypes related to men: do not show emotions, do not cry, messy

Source: E. Mandal, Podmiotowe i interpersonalne konsekwencje stereotypów związanych z płcią, Katowice 2004; M. Grabowska, Stereotypy płci we wczesnej dorosłości, Bydgoszcz 2007; M. Długołęcka, Raport o seksualności Polaków - Pfizer, Warszawa 2002.

The image of masculity and feminity shapes in our mind in socialisation process in which we achieve knowledge about common standards, values and rules which regulate life in particular society. Gender stereotypes are implanted in that stage. By them, we concrete image of man and woman in our head. The key source of creating this image is raising environment which consists of mainly family and school. ${ }^{21}$

It emerges that soon after birth parents choose the way of treating the child. They treat differently boys and girls. Girls are treated more delicate, their parent express calm, however towards boys parents try to transmit features such as activity and strength..$^{22}$

Moreover, children follow example by observing models and how particular behaviours connected with gender are rewarded. After that, they get assignments in school which are related to gender stereotypes, primarily to components of social roles. According to Chomczyńskiej-Miliszkiewicz ${ }^{23}$,

${ }^{21}$ E. Napora, Skrzydła i korzenie, Niebieska Linia, 2005, 2.

22 A. Buczkowski, Dwa różne światy, czyli jak socjalizuje się dziewczynkę i chłopca, [w]: BrachCzaina, Od kobiety do mężczyzny i z powrotem. Rozważania o ptci w kulturze, Białystok 1997.

${ }^{23}$ M. Chomczyńska-Miliszkiewicz, Edukacja seksualna w społeczeństwie wspótczesnym. Konteksty pedagogiczne i psychospołeczne, Lublin 2002. 
girls decorate classrooms or prepare meals on school trips, whilst boys are responsible for music, picking brushwood or carrying banner. All these premises render that women in adult life present compliant and dependent attitude, while men beam with independence and dominance. ${ }^{24}$

Writing about gender stereotypes it is essential to concern their consequences and by doing this explain the scale of this article. One of the consequences is sexism which is almost direct result of gender stereotypicalisation. This system of negative attitudes and related to them behaviours that refer to the gender, constitute the expression of discrimination - in the education, word and family realm. The sexism in education realm may be seen in encouraging women to develop in humane or artistic field and discouraging them to develop in science. This system concerns also men. By sexism we prove to be close-minded in some patterns which prevent our self-realisation connected with developing our talents and hobbies. ${ }^{25}$

There was conducted a study which aimed to recognition how much modern vision of masculity and feminity is congruent with gender stereotypes. The study was derivated from six components of gender stereotypes which were presented before (see Table 1). Mentioned above image of masculity and feminity constitute dependent variable. Gender stereotypes of six fields (appearance, personality, social roles, profession, behaviour, sexual life) constitute independent variable. Indicating devices are: the number of followed stereotypes in the field of appearance, personality, social roles, profession, behaviour and sexual life.

The study was conveyed by the quantitative measure method, more specific diagnostic survey. In this survey the multivariate scale (semantic differential), made by the author, was used. Interviewee pointed to which extend they agree that particular feature describes man or woman. The answers have determined points assigned (different concerning stereotypical features of men and women)

In the survey attended 141 interviewees (41 men and 100 women) in age of 19 to 60 years old, heterosexual orientation.

There was a distinction into results concerning stereotypical male and female features and they were assigned to appropriate categories (appearance, personality, social roles, profession, behaviours and sexual life). Then the actual amount of answers was assigned to each feature.

There was weighted average calculated to every result concerning both male and female features in every category presented above. The results were

${ }^{24}$ M. Drost-Rudnicka, Edukacja wczesnoszkolna a problem nierówności płci - uczniowskie stereotypy postrzegania ptci, [w:] Podmiotowość w edukacji wobec odmienności kulturowych oraz społecznych zróżnicowań, Eds. N. Majchrzak, N. Starik, A. Zduniak, Poznań 2012.

${ }^{25}$ M. Grabowska, Stereotypy ptci. 
Table 2

The number of points assigned to answers concerning stereotypical features of men and women

\begin{tabular}{|l|c|c|}
\hline \multicolumn{1}{|c|}{ Type of the answer } & $\begin{array}{c}\text { The number of points } \\
\text { for features stereoty- } \\
\text { pically male }\end{array}$ & $\begin{array}{c}\text { The number of points } \\
\text { for features stereoty- } \\
\text { pically female }\end{array}$ \\
\hline $\begin{array}{l}\text { "I strongly agree that this feature de- } \\
\text { scribes a woman" }\end{array}$ & 1 & 5 \\
\hline $\begin{array}{l}\text { "I agree that this feature describes } \\
\text { a woman" }\end{array}$ & 2 & 3 \\
\hline $\begin{array}{l}\text { "This feature describes neither a man nor } \\
\text { a woman” }\end{array}$ & 3 & 2 \\
\hline $\begin{array}{l}\text { "I strongly agree that this feature de- } \\
\text { scribes a man" }\end{array}$ & 4 & 1 \\
\hline $\begin{array}{l}\text { "I agree that this feature describes } \\
\text { a man" }\end{array}$ & 5 & \\
\hline
\end{tabular}

Source: Author's study.

an established explicitation of ranges of evaluated weighted average concerning masculity and feminity.

$9,4-22 \rightarrow$ low congruence of masculity and feminity image with gender stereotypes;

$23-36 \rightarrow$ congruence of masculity and feminity image with gender stereotypes in average level;

$>36 \rightarrow$ high congruence of masculity and feminity image with gender stereotypes.

The results of the study (see Table 3) show high congruence of feminity image and common gender stereotypes concerning appearance (granted that $(\bar{x}=\approx 39,5)$. In this category charm is the most dominant feature with the highest amount of weighted average $(\bar{x}=\approx 42)$. It seems to be the most common of stereotype's components concerning women's appearance. Another feature which has the high level of congruence while describing feminity as stereotype is subtle voice $(\bar{x}=\approx 41,5)$ next in the hierarchy are soft moves $(\bar{x}=$ $\approx 40$ ) and cleanliness, which is the only one of the appearance's components that has the average level $(\bar{x}=\approx 34,5)$ of congruence with the feminity.

The high congruence of feminity image and gender stereotypes is also seen concerning personality features $(\bar{x}=\approx 37)$. The components in descending order (by the amount of weighted average $(\bar{x})$ are as follows: sensitivity $(\approx 41,3)$, emotionality $(\approx 41)$, care of others' feelings $(\approx 38,7)$, warm in social relations $(\approx 37,4)$, understanding $(\approx 37,3)$, fondness $(\approx 36,3)$, commitment $(\approx 34,8)$, curiosity $(\approx 34,4)$, helping $(\approx 32)$. Only three stereotypical features concerning personality have average level of congruence with modern feminity image (commitment, curiousity and helping). 
Table 3

The results of the studies of congruence of feminity image concerning appearance with common gender stereotypes

\begin{tabular}{|l|c|c|c|c|c|}
\hline \multicolumn{1}{|c|}{ Stereotypical features of woman } \\
\hline Appearance $(\bar{x}=\approx 39,5)$ & $\begin{array}{c}\text { I strongly } \\
\text { agree that } \\
\text { this feature } \\
\text { describes } \\
\text { a woman }\end{array}$ & $\begin{array}{c}\text { I agree } \\
\text { that this } \\
\text { feature } \\
\text { describes } \\
\text { a woman }\end{array}$ & $\begin{array}{c}\text { This feature } \\
\text { describes } \\
\text { neither } \\
\text { a man nor } \\
\text { a woman }\end{array}$ & $\begin{array}{c}\text { I agree } \\
\text { that this } \\
\text { feature } \\
\text { describes } \\
\text { a man }\end{array}$ & $\begin{array}{c}\text { I strongly } \\
\text { agree that } \\
\text { this feature } \\
\text { describes } \\
\text { a man }\end{array}$ \\
\hline Charm & 76 & 53 & 11 & 0 & 1 \\
\hline Soft moves & 62 & 57 & 20 & 0 & 2 \\
\hline Cleanliness & 31 & 46 & 56 & 3 & 5 \\
\hline Subtle voice & 70 & 60 & 11 & 0 & 0 \\
\hline
\end{tabular}

Source: Author's study.

Table 4

The results of the studies of congruence of feminity image concerning personality with common gender stereotypes

\begin{tabular}{|l|c|c|c|c|c|}
\hline \multicolumn{7}{|c|}{ Stereotypical features of woman } \\
\hline Personality $(\bar{x}=\approx 37)$ & $\begin{array}{c}\text { I strongly } \\
\text { agree that } \\
\text { this feature } \\
\text { describes } \\
\text { a woman }\end{array}$ & $\begin{array}{c}\text { I agree } \\
\text { that this } \\
\text { feature } \\
\text { describes } \\
\text { a woman }\end{array}$ & $\begin{array}{c}\text { This feature } \\
\text { describes } \\
\text { neither } \\
\text { a man nor } \\
\text { a woman }\end{array}$ & $\begin{array}{c}\text { I agree } \\
\text { that this } \\
\text { feature } \\
\text { describes } \\
\text { a man }\end{array}$ & $\begin{array}{c}\text { I strongly } \\
\text { agree that } \\
\text { this feature } \\
\text { describes } \\
\text { a man }\end{array}$ \\
\hline Commitment & 44 & 35 & 43 & 14 & 5 \\
\hline $\begin{array}{l}\text { Care of others' } \\
\text { feelings }\end{array}$ & 49 & 65 & 23 & 3 & 1 \\
\hline $\begin{array}{l}\text { Warm in social } \\
\text { relations }\end{array}$ & 40 & 61 & 37 & 3 & 0 \\
\hline Helping & 79 & 35 & 76 & 8 & 3 \\
\hline Emotionality & 70 & 50 & 21 & 0 & 0 \\
\hline Sensitivity & 45 & 46 & 38 & 9 & 3 \\
\hline Fondness & 43 & 61 & 29 & 5 & 3 \\
\hline Understanding & 35 & 42 & 49 & 11 & 4 \\
\hline Curiosity & & & & & 0 \\
\hline
\end{tabular}

Source: Author's study. 
Table 5

The results of the studies of congruence of feminity image concerning profession with common gender stereotypes

\begin{tabular}{|l|c|c|c|c|c|}
\hline \multicolumn{7}{|c|}{ Stereotypical features of woman } \\
\hline Profession $(\bar{x}=\approx 35)$ & $\begin{array}{c}\text { I strongly } \\
\text { agree that } \\
\text { this feature } \\
\text { describes } \\
\text { a woman }\end{array}$ & $\begin{array}{c}\text { I agree } \\
\text { that this } \\
\text { feature } \\
\text { describes } \\
\text { a woman }\end{array}$ & $\begin{array}{c}\text { This } \\
\text { feature } \\
\text { describes } \\
\text { neither } \\
\text { a man nor } \\
\text { a woman }\end{array}$ & $\begin{array}{c}\text { I agree } \\
\text { that this } \\
\text { feature } \\
\text { describes } \\
\text { a man }\end{array}$ & $\begin{array}{c}\text { I strongly } \\
\text { agree that this } \\
\text { feature } \\
\text { describes } \\
\text { a man }\end{array}$ \\
\hline Nurses & 25 & 57 & 56 & 2 & 1 \\
\hline Makes calls & 19 & 26 & 85 & 7 & 4 \\
\hline Teaches kids & 38 & 57 & 45 & 1 & 0 \\
\hline $\begin{array}{l}\text { Carries } \\
\text { out therapy }\end{array}$ & 24 & 38 & 75 & 1 & 3 \\
\hline $\begin{array}{l}\text { Corrects speech } \\
\text { impediment }\end{array}$ & 34 & 60 & 44 & 1 & 2 \\
\hline
\end{tabular}

Source: Author's study.

The feminity image seems to be congruent with common gender stereotypes concerning profession in the average level. Only primary school teacher $(\bar{x}=\approx 37)$ and speech therapist $(\bar{x}=\approx 36,4)$ have a high level of congruence with the image of a modern woman. Other components, such as nurse $(\bar{x}=\approx 35,2)$ therapeutant $(\bar{x}=\approx 33,5)$ or telephonist $(\bar{x}=\approx 31,5)$ have an average level of congruence with the image of a modern woman (see Table 5).

Basing on the table above (Table 6), it is seen that the feminity image is congruent with common gender stereotypes concerning social roles in the average level $(\bar{x}=\approx 36)$. The high congruence in this category has the role of taking care of children $(\bar{x}=\approx 37)$ and managing the house $(\bar{x}=\approx 36,3)$. Other components have the average level of congruence with the modern feminity image (decorating the house, where $\bar{x}=\approx 35,8$, being an emotional support, where $\bar{x}=\approx 35,6$.

The level of congruence with the feminity image in stereotypes concerning behaviour (see Table 7) is high $(\bar{x}=\approx 38)$. The highest amount of the weighted average $(\bar{x})$ has changing of moods $(\bar{x}=\approx 39,5)$, at the second place there is being flirtatious $(\approx 38,5)$ and the last component is gossiping $(\approx 35)$. 
Table 6

The results of the studies of congruence of feminity image concerning social roles with common gender stereotypes

\begin{tabular}{|l|c|c|c|c|c|}
\hline \multicolumn{7}{|c|}{ Stereotypical features of woman } \\
\hline Social roles $(\bar{x}=\approx 36)$ & $\begin{array}{c}\text { I strongly } \\
\text { agree that } \\
\text { this feature } \\
\text { describes } \\
\text { a woman }\end{array}$ & $\begin{array}{c}\text { I agree } \\
\text { that this } \\
\text { feature } \\
\text { describes } \\
\text { a woman }\end{array}$ & $\begin{array}{c}\text { This } \\
\text { feature } \\
\text { describes } \\
\text { neither } \\
\text { a man nor } \\
\text { a woman }\end{array}$ & $\begin{array}{c}\text { I agree } \\
\text { that this } \\
\text { feature } \\
\text { describes } \\
\text { a man }\end{array}$ & $\begin{array}{c}\text { I strongly } \\
\text { agree that } \\
\text { this feature } \\
\text { describes } \\
\text { a man }\end{array}$ \\
\hline Manages the house & 33 & 61 & 42 & 4 & 1 \\
\hline Decorates the house & 38 & 49 & 46 & 5 & 3 \\
\hline $\begin{array}{l}\text { Is an emotional sup- } \\
\text { port to others }\end{array}$ & 39 & 53 & 32 & 14 & 3 \\
\hline $\begin{array}{l}\text { Takes care of chil- } \\
\text { dren }\end{array}$ & 40 & 56 & 43 & 2 & 0 \\
\hline
\end{tabular}

Source: Author's study.

Table 7

The results of the studies of congruence of feminity image concerning behaviour with common gender stereotypes

\begin{tabular}{|l|c|c|c|c|c|}
\hline \multicolumn{1}{|c|}{ Stereotypical features of woman } \\
\hline Behaviour $(\bar{x}=\approx 38)$ & $\begin{array}{c}\text { I strongly } \\
\text { agree that } \\
\text { this feature } \\
\text { describes } \\
\text { a woman }\end{array}$ & $\begin{array}{c}\text { I agree that } \\
\text { this feature } \\
\text { describes } \\
\text { a woman }\end{array}$ & $\begin{array}{c}\text { This } \\
\text { feature } \\
\text { describes } \\
\text { neither } \\
\text { a man nor } \\
\text { a woman }\end{array}$ & $\begin{array}{c}\text { I agree that } \\
\text { this feature } \\
\text { describes } \\
\text { a man }\end{array}$ & $\begin{array}{c}\text { I strongly } \\
\text { agree that } \\
\text { this feature } \\
\text { describes } \\
\text { a man }\end{array}$ \\
\hline Gossips & 31 & 48 & 51 & 8 & 3 \\
\hline $\begin{array}{l}\text { Has changing } \\
\text { moods }\end{array}$ & 60 & 53 & 25 & 2 & 1 \\
\hline Is flirtatious & 51 & 61 & 23 & 3 & 3 \\
\hline
\end{tabular}

Source: Author's study.

In the field of the last category - sexual life, there is an average congruence of the feminity image with the common gender stereotypes $(\bar{x}=\approx 35)$ 
Table 8

The results of the studies of congruence of feminity image concerning sexual life with common gender stereotypes

\begin{tabular}{|l|c|c|c|c|c|}
\hline \multicolumn{5}{|c|}{ Stereotypical features of woman } \\
\hline Sexual life $(\bar{x}=\approx 35)$ & $\begin{array}{c}\text { I strongly } \\
\text { agree that } \\
\text { this feature } \\
\text { describes } \\
\text { a woman }\end{array}$ & $\begin{array}{c}\text { I agree that } \\
\text { this feature } \\
\text { describes } \\
\text { a woman }\end{array}$ & $\begin{array}{c}\text { This feature } \\
\text { describes } \\
\text { neither } \\
\text { a man nor } \\
\text { a woman }\end{array}$ & $\begin{array}{c}\text { I agree that } \\
\text { this feature } \\
\text { describes } \\
\text { a man }\end{array}$ & $\begin{array}{c}\text { I strongly } \\
\text { agree that } \\
\text { this feature } \\
\text { describes } \\
\text { a man }\end{array}$ \\
\hline $\begin{array}{l}\text { Gets ple- } \\
\text { asure out } \\
\text { of sex only } \\
\text { with sense } \\
\text { of emotional } \\
\text { connection }\end{array}$ & 29 & 51 & 56 & 1 & 4 \\
\hline $\begin{array}{l}\text { Has greater } \\
\text { control on } \\
\text { her sexual } \\
\text { needs }\end{array}$ & 31 & 55 & 49 & 4 & 2 \\
\hline
\end{tabular}

Source: Author's study.

Having the greater control on the sexual needs seems to be assigned to women more frequent $(\bar{x}=\approx 35,5)$ than the component of getting the pleasure out of sex only with sense of emotional connection $(\bar{x}=\approx 34,9)$.

Table 9

The results of the studies of congruence of masculity image concerning appearance with common gender stereotypes

\begin{tabular}{|l|c|c|c|c|c|}
\hline \multicolumn{7}{|c|}{ Stereotypical features of man } \\
\hline Appearance $(\bar{x}=\approx 40)$ & $\begin{array}{c}\text { I strongly } \\
\text { agree that } \\
\text { this feature } \\
\text { describes } \\
\text { a woman }\end{array}$ & $\begin{array}{c}\text { I agree that } \\
\text { this feature } \\
\text { describes } \\
\text { a woman }\end{array}$ & $\begin{array}{c}\text { This feature } \\
\text { describes } \\
\text { neither } \\
\text { a man nor } \\
\text { a woman }\end{array}$ & $\begin{array}{c}\text { I agree that } \\
\text { this feature } \\
\text { describes } \\
\text { a man }\end{array}$ & $\begin{array}{c}\text { I strongly } \\
\text { agree that } \\
\text { this feature } \\
\text { describes } \\
\text { a man }\end{array}$ \\
\hline Robust & 2 & 2 & 23 & 55 & 59 \\
\hline Strong & 1 & 4 & 19 & 57 & 60 \\
\hline Tall & 0 & 0 & 33 & 58 & 50 \\
\hline $\begin{array}{l}\text { Broad-shoul- } \\
\text { dered }\end{array}$ & 0 & 1 & 12 & 53 & 75 \\
\hline
\end{tabular}

Source: Author's study. 
The masculity image concerning appearance (similarly to the feminity image) has a high level of congruence with the gender stereotypes $(\bar{x}=\approx 40)$ The most commonly described as masculine are features: broad-shouldered figure $(\bar{x}=\approx 41,7)$ and strength $(\bar{x}=\approx 40)$. On the third place there is robustness $(\bar{x}=\approx 39,3)$ and then tallness $(\bar{x}=\approx 38,7)$, which still has a high level of congruence with the modern masculity image (see Table 9).

The masculity image is congruent with the gender stereotypes concerning personality in the average level $(\bar{x}=\approx 29)$. The descending order of the components (by the amount of weighted average $(\bar{x})$ ) is as follows: the sense of leadership $(\approx 36,6)$, ease in decision-making $(\approx 34)$, not undergoing the pressure $(\approx 33)$, self-belief $(\approx 32,4)$, activity $(\approx 32)$, independence $(\approx 28,2)$, reliability $(\approx 27,9)$, proficiency $(\approx 26,9)$, jealousy $(\approx 24)$. The most commonly assigned feature in this category is the sense of leadership which is congruent with the modern masculity image in the high level (see Table 10).

Table 10

The results of the studies of congruence of masculity image concerning personality with common gender stereotypes

\begin{tabular}{|l|c|c|c|c|c|}
\hline \multicolumn{7}{|c|}{ Stereotypical features of man } \\
\hline Personality $((\bar{x}=\approx 29)$ & $\begin{array}{c}\text { I strongly } \\
\text { agree that } \\
\text { this feature } \\
\text { describes } \\
\text { a woman }\end{array}$ & $\begin{array}{c}\text { I agree that } \\
\text { this feature } \\
\text { describes } \\
\text { a woman }\end{array}$ & $\begin{array}{c}\text { This feature } \\
\text { describes } \\
\text { neither } \\
\text { a man nor } \\
\text { a woman }\end{array}$ & $\begin{array}{c}\text { I agree that } \\
\text { this feature } \\
\text { describes } \\
\text { a man }\end{array}$ & $\begin{array}{c}\text { I strongly } \\
\text { agree that } \\
\text { this feature } \\
\text { describes } \\
\text { a man }\end{array}$ \\
\hline Self-belief & 8 & 9 & 63 & 34 & 27 \\
\hline $\begin{array}{l}\text { Sense of leader- } \\
\text { ship }\end{array}$ & 8 & 4 & 27 & 58 & 44 \\
\hline Activity & 8 & 12 & 61 & 39 & 21 \\
\hline $\begin{array}{l}\text { Ease in deci- } \\
\text { sion-making }\end{array}$ & 3 & 14 & 43 & 53 & 28 \\
\hline $\begin{array}{l}\text { Not undergoing } \\
\text { the pressure }\end{array}$ & 5 & 11 & 50 & 52 & 23 \\
\hline Independence & 19 & 20 & 56 & 26 & 20 \\
\hline Proficiency & 13 & 28 & 77 & 12 & 11 \\
\hline Reliability & 13 & 24 & 72 & 19 & 13 \\
\hline Jealousy & 27 & 36 & 53 & 23 & 2 \\
\hline
\end{tabular}

Source: Author's study.

The masculity image is congruent with the gender stereotypes concerning profession in the average level $(\bar{x}=\approx 33)$. The high congruence is ob- 
served in components (see Table 11) such as: lorry driver $(\bar{x}=\approx 39,7)$ or telephones fitter $(\bar{x}=\approx 38,7)$. Other professions are not as commonly assigned to men and those are: mayor $(\bar{x}=\approx 34)$, insurance agent $(\bar{x}=\approx 28,9)$ or chemist $(\bar{x}=\approx 25)$.

Table 11

The results of the studies of congruence of masculity image concerning profession with common gender stereotypes

\begin{tabular}{|l|c|c|c|c|c|}
\hline \multicolumn{1}{|c|}{ Stereotypical features of man } \\
\hline Profession $(\bar{x}=\approx 33)$ & $\begin{array}{c}\text { I strongly } \\
\text { agree } \\
\text { that this } \\
\text { feature } \\
\text { describes } \\
\text { a woman }\end{array}$ & $\begin{array}{c}\text { I agree } \\
\text { that this } \\
\text { feature } \\
\text { describes } \\
\text { a woman }\end{array}$ & $\begin{array}{c}\text { This feature } \\
\text { describes } \\
\text { neither } \\
\text { a man nor } \\
\text { a woman }\end{array}$ & $\begin{array}{c}\text { I agree } \\
\text { that this } \\
\text { feature } \\
\text { describes } \\
\text { a man }\end{array}$ & $\begin{array}{c}\text { I strongly } \\
\text { agree that } \\
\text { this feature } \\
\text { describes } \\
\text { a man }\end{array}$ \\
\hline Drives a lorry & 0 & 0 & 28 & 53 & 60 \\
\hline Manages a city & 2 & 4 & 67 & 40 & 28 \\
\hline $\begin{array}{l}\text { Is an insurance } \\
\text { agent }\end{array}$ & 8 & 17 & 84 & 21 & 11 \\
\hline $\begin{array}{l}\text { Works as chem- } \\
\text { ist }\end{array}$ & 15 & 31 & 85 & 8 & 2 \\
\hline Fits telephones & 0 & 0 & 22 & 80 & 39 \\
\hline
\end{tabular}

Source: Author's study.

The average level of congruence between the masculity image and gender stereotypes i salso observed in the field of social roles $(\bar{x}=\approx 35)$. As seen in the table below (Table 12) the sense of leadership $(\bar{x}=\approx 36,6)$ and repairing the house $(\bar{x}=\approx 38,3)$ are congruent with the common masculity image in the high level. The average level of congruence between the gender stereotypes and the modern masculity image is seen in features such as: financial support of the family $(\bar{x}=\approx 35)$ and being a spearhead $(\bar{x}=\approx 30,3)$.

The masculity image seems to be congruent in the average level with gender stereotypes concerning behaviour $(\bar{x}=\approx 36)$. Men are said to (see Table 13) do not show emotions $(\bar{x}=\approx 36,8)$ and do not cry $(\bar{x}=\approx 38,2)$. The average level of congruency with the masculity image is seen in being messy $(\bar{x}=\approx 32,3)$.

The congruency concerning sexual life (see Table 14) in the masculity image with the common gender stereotypes is also on the average level $(\bar{x}=\approx 35)$. The results on this field are similar to the results concerning feminity, where answers are analogical to these presented below. The respondents decide that men have fewer control on their sexual needs $(\bar{x}=\approx 35,5)$ and that they get sexual pleasure out of sex even with strangers $(\bar{x}=\approx 34,5)$. 
Table 12

The results of the studies of congruence of masculity image concerning social roles with common gender stereotypes

\begin{tabular}{|l|c|c|c|c|c|}
\hline \multicolumn{5}{|c|}{ Stereotypical features of man } \\
\hline Social roles $(\bar{x}=\approx 35)$ & $\begin{array}{c}\text { I strongly } \\
\text { agree that } \\
\text { this feature } \\
\text { describes } \\
\text { a woman }\end{array}$ & $\begin{array}{c}\text { I agree that } \\
\text { this feature } \\
\text { describes } \\
\text { a woman }\end{array}$ & $\begin{array}{c}\text { This feature } \\
\text { describes } \\
\text { neither } \\
\text { a man nor } \\
\text { a woman }\end{array}$ & $\begin{array}{c}\text { I agree that } \\
\text { this feature } \\
\text { describes } \\
\text { a man }\end{array}$ & $\begin{array}{c}\text { I strongly } \\
\text { agree that } \\
\text { this feature } \\
\text { describes } \\
\text { a man }\end{array}$ \\
\hline $\begin{array}{l}\text { Financially } \\
\text { supports the } \\
\text { family }\end{array}$ & 0 & 2 & 59 & 55 & 25 \\
\hline $\begin{array}{l}\text { Repairs the } \\
\text { house }\end{array}$ & 6 & 2 & 19 & 62 & 52 \\
\hline $\begin{array}{l}\text { Is the head } \\
\text { of the house- } \\
\text { hold }\end{array}$ & 17 & 14 & 51 & 38 & 21 \\
\hline $\begin{array}{l}\text { Is a spear- } \\
\text { head }\end{array}$ & 8 & 4 & 27 & 58 & 44 \\
\hline
\end{tabular}

Source: Author's study.

Table 13

The results of the studies of congruence of masculity image concerning behaviour with common gender stereotypes

\begin{tabular}{|l|c|c|c|c|c|}
\hline \multicolumn{7}{|c|}{ Stereotypical features of man } \\
\hline Behaviour $(\bar{x}=\approx 36)$ & $\begin{array}{c}\text { I strongly } \\
\text { agree that } \\
\text { this feature } \\
\text { describes } \\
\text { a woman }\end{array}$ & $\begin{array}{c}\text { I agree that } \\
\text { this feature } \\
\text { describes } \\
\text { a woman }\end{array}$ & $\begin{array}{c}\text { This feature } \\
\text { describes } \\
\text { neither } \\
\text { a man nor } \\
\text { a woman }\end{array}$ & $\begin{array}{c}\text { I agree that } \\
\text { this feature } \\
\text { describes } \\
\text { a man }\end{array}$ & $\begin{array}{c}\text { I strongly } \\
\text { agree that } \\
\text { this feature } \\
\text { describes } \\
\text { a man }\end{array}$ \\
\hline Does not cry & 0 & 1 & 28 & 73 & 39 \\
\hline $\begin{array}{l}\text { Does not } \\
\text { show emo- } \\
\text { tions }\end{array}$ & 0 & 2 & 45 & 57 & 37 \\
\hline $\begin{array}{l}\text { Makes } \\
\text { a mess }\end{array}$ & 7 & 6 & 67 & 40 & 21 \\
\hline
\end{tabular}

Source: Author's study. 
Table 14

The results of the studies of congruence of masculity image concerning sexual life with common gender stereotypes

\begin{tabular}{|l|c|c|c|c|c|}
\hline \multicolumn{5}{|c|}{ Stereotypical features of man } \\
\hline Sexual life $(\bar{x}=\approx 35)$ & $\begin{array}{c}\text { I strongly } \\
\text { agree that } \\
\text { this feature } \\
\text { describes } \\
\text { a woman }\end{array}$ & $\begin{array}{c}\text { I agree that } \\
\text { this feature } \\
\text { describes } \\
\text { a woman }\end{array}$ & $\begin{array}{c}\text { This feature } \\
\text { describes } \\
\text { neither } \\
\text { a man nor } \\
\text { a woman }\end{array}$ & $\begin{array}{c}\text { I agree that } \\
\text { this feature } \\
\text { describes } \\
\text { a man }\end{array}$ & $\begin{array}{c}\text { I strongly } \\
\text { agree that } \\
\text { this feature } \\
\text { describes } \\
\text { a man }\end{array}$ \\
\hline $\begin{array}{l}\text { Gets ple- } \\
\text { asure out of } \\
\text { sex without } \\
\text { sense of } \\
\text { emotional } \\
\text { connection }\end{array}$ & 0 & 4 & 65 & 46 & 26 \\
\hline $\begin{array}{l}\text { Has a fewer } \\
\text { control on } \\
\text { his sexual } \\
\text { needs }\end{array}$ & 1 & 6 & 46 & 58 & 30 \\
\hline
\end{tabular}

Source: Author's study.

Summing up presented results of the study, it is essential to highlight that masculity and feminity image is congruence with the common gender stereotypes. Mainly, the congruency is on the average level, however; there is occasionally a high level of congruency - i.e. concerning appearance, personality and behaviour of women and appearance of men. The feminity image seems to be generated by the gender stereotypes in the higher level than the masculity image.

\section{BIBLIOGRAPHY}

Allport G., Personality: A psychological interpretation, H. Holt and Company, New York 1937. Brannon L., Psychologia rodzaju. Kobiety i mężczyźni: podobni czy różni, Gdańskie Wydawnictwo Psychologiczne, Gdańsk 2002.

Buczkowski A., Dwa różne światy, czyli jak socjalizuje się dziewczynkę i chłopca, [w]: BrachCzaina, Od kobiety do mężczyzny i z powrotem. Rozważania o ptci w kulturze, Trans Humana, Białystok 1997.

Chlewiński Z., Stereotypy: struktura, funkcje, geneza. Analiza interdyscyplinarna, [w:] Stereotypy i uprzedzenia, Eds. Z. Chlewiński, I. Kurcz, Instytut Psychologii PAN, Warszawa 1992. 
Chomczyńska-Miliszkiewicz M., Edukacja seksualna w społeczeństwie współczesnym. Konteksty pedagogiczne i psychospołeczne, Wydawnictwo Uniwersytetu Marii Curie-Skłodowskiej, Lublin 2002.

Cross S., Markus H.R., Płeć w myśleniu, przekonaniach i działaniu: podejście poznawcze, [w:] Kobiety i mężczyźni. Odmienne spojrzenia na różnice, Ed. B. Wojciszke, Gdańskie Wydawnictwo Psychologiczne, Gdańsk 2002.

Długołęcka M., Raport o seksualności Polaków - Pfizer, SMG KRC, Warszawa 2002.

Drost-Rudnicka M., Edukacja wczesnoszkolna a problem nierówności ptci - uczniowskie stereotypy postrzegania ptci, [w:] Podmiotowość w edukacji wobec odmienności kulturowych oraz społecznych zróżnicowań, Eds. N. Majchrzak, N. Starik, A. Zduniak, Wydawnictwo Wyższej Szkoły Bezpieczeństwa, Poznań 2012.

Grabowska M., Stereotypy ptci we wczesnej dorostości, Wydawnictwo Uniwersytetu Kazimierza Wielkiego, Bydgoszcz 2007.

Mandal E., Kobiecość i męskość. Popularne opinie a badania naukowe, Wydawnictwo Akademickie Żak, Warszawa 2003.

Mandal E., Podmiotowe i interpersonalne konsekwencje stereotypów związanych z płcia, Wydawnictwo Uniwersytetu Śląskiego, Katowice 2004.

Napora E., Skrzydta i korzenie, Niebieska Linia, 2005, 2.

Okoń W., Nowy stownik pedagogiczny, Wydawnictwo Akademickie Żak, Warszawa 2001.

Wojciszke B., Człowiek wśród ludzi. Zarys psychologii społecznej, Wydawnictwo Naukowe Scholar, Warszawa 2003. 